\title{
Pengaruh Pencemaran Limbah Detergen terhadap Biota Air
}

\author{
Isti’anah, Sayyidatun Najah, dan Selvy Hani Putri Pratiwi ${ }^{1}$ \\ Email: aisti262@gmail.com
}

1) Program Studi S1 Ilmu Lingkungan Fakultas Teknik Universitas Islam Lamongan

\begin{abstract}
ABSTRAK
Pencemaran air adalah masuknya atau dimasukkanya makhluk hidup, zat, energi dan atau komponen lain kedalam air oleh kegiatan manusia, sehingga kualitas air turun sampai ketingkat tertentu yang menyebabkan air tidak dapat berfungsi sesuai dengan fungsinya. Salah satu yang menyebabkan air tercemar adalah buangan limbah domestik berupa detergen. Tujuan penelitian ini adalah menganalisis seberapa jauh pengaruh detergen terhadap tingkah laku ikan. Hal ini bisa dijadikan sebagai bio indikator bahwa sungai tersebut sudah tercemar. Hasil penelitian didapatkan bahwa sebagian masyarakat menjadikan sungai sebagai bahan buangan limbah termasuk limbah domestik (detergen) yang berpengaruh terhadap makhluk hidup yang ada di dalamnya, salah satunya adalah ikan. Hasil penelitian ini menunjukkan bahwa semakin banyak detergen yang terkandung didalam air maka semakin berpengaruh pula terhadap kelangsungan hidup ikan. Seperti kejang-kejang, mengeluarkan lendir, insang berdarah, bahkan langsung mati. Penelitian ini diharapkan bisa bermanfaat dan menjadi masukan bagi masyarakat dalam menjaga dan melestarikan lingkungan. Agar kehidupan masyarakat lebih terjaga dan jauh dari penyakit.
\end{abstract}

Kata kunci: Pencemaran Air, Detergen, Biota air.

\section{PENDAHULUAN}

Sungai adalah salah satu unsur penting dalam kehidupan manusia, karena sungai menyediakan air bagi kebutuhan manusia dalam melakukan aktivitasnya. Namun pada saat ini aktivitas manusia semakin meningkat, hal ini sejalan dengan peningkatan kasus pencemaran air. Kasus pencemaran air muncul karena adanya pergeseran fungsi utama dari sungai itu sendiri. Fungsi utama sungai adalah mengalirkan air dari hulu ke hilir demi pemenuhan kebutuhan manusia, namun saat ini fungsi sungai berubah menjadi media yang mudah dan murah untuk pembuangan limbah, termasuk dalam limbah domestik seperti halnya detergen.

Hasil pemantauan di lapangan, setiap sungai ini ternyata digunakan untuk keperluan pertanian, pengairan, dan keperluan rumah tangga. Air dari selokan dimanfaatkan warga untuk sumber air tambak ikan. Limbah buangan dari tambak tersebut kemudian mengalir kembali ke sungai. Hal ini menyebabkan masuknya bahan-bahan cemaran ke sungai yang berpengaruh pada kualitas air sungai yang mengakibatkan tumbuhnya bluming eceng gondok. Pertumbuhan eceng gondok menandakan banyaknya bahan tercemar yang terdapat di air sungai, seperti pupuk kimia, detergen, dan limbah pertanian. Pesatnya tumbuhan eceng gondok juga berdampak pada popolasi ikan yang ada di sungai. Detergen, didalamnya mengandung senyawa kimia seperti Alkyl Benzene Sulpohnate (ABS) yang bersifat resisten terhadap dekomposisi biologis.

Pencemaran air adalah masuknya atau dimasukkanya makhluk hidup, zat, energi dan atau komponen lain kedalam air oleh kegiatan manusia, sehingga kualitas air turun sampai ketingkat tertentu yang menyebabkan air tidak dapat berfungsi sesuai dengan peruntukkanya. Status mutu air adalah tingkat kondisi mutu air yang menunjukkan kondisi cemar atau kondisi baik pada suatu sumber air dalam waktu tertentu dengan membandingkan baku mutu air yang ditetapkan. Baku mutu air adalah batas kadar yang di perbolehkan bagi zat atau bahan tercemar terdapat dalam air, namun air tetap berfungsi sesuai dengan peruntukkanya. Baku mutu limbah cair dalah batas kadar yang diperbolehkan bagi zat atau bahan pencemar untuk dibuang dari sumber pencemaran ke dalam air pada sumber air, sehingga tidak mengakibatkan dilampauinya baku mutu air. Salah satu bahan pencemaran air adalah detergen. Baku mutu limbah cair yang berupa detergen ditetapkan sebesar 2 ppm.

Air limbah detergen termasuk polutan karena didalamnya terdapat zat yang disebut ABS. Jenis detergen yang banyak digunakan di rumah tangga 
sebagai bahan pencuci pakaian adalah detergen anti noda. Detergen generasi awal muncul menggunakan bahan kimia pengaktif permukaan (surfaktan) Alkyl Benzene Sulfonat (ABS) yang mampu menghasilkan busa. Namun karena sifat ABS yang sulit di urai oleh mikroorganisme di permukaan tanah, akhirnya di gantikan dengan senyawa Linier Alkyl Sulfonat (LAS) yang diyakini relatif lebih akrab dengan lingkungan. Walau lebih ramah lingkungan, detergen tidak berarti ramah bagi organisme dalam air. Jika detergen yang larut dalam air cukup signifikal, maka dapat mematikan ikan yang hidup didalamnya. Ikan mengambil oksigen yang terlarut dalam air memalui ingsannya. Dengan adanya detergen yang larut dalam air, maka zat tersebut akan masuk kedalam tubuh ikan langsung pada sistem sirkulasinya. Keberadaan zat ini mengganggu metabolisme ikan, jika melebihi ambang batas ikan akan mati.

Ikan mas (Cyprinus carpio) adalah organisme air yang responsif atau peka terhadap perubahan yang terjadi pada lingkungannya. Insang adalah alat yang digunakan untuk bernafas. Pada insang terjadi pertukaran $\mathrm{O} 2$ dan $\mathrm{CO} 2$. Mekanismenya adalah tutup insang menutup, mulut terbuka, air masuk melalui mulut, lalu air melewati insang, terjadi pertukaran oksigen dan karbondioksida, lalu mulut menutup, tutup insang (operculum) terbuka, dan akhirnya air keluar dari insang. Oksigen masuk ke aliran darahnya. Jika dalam air terdapat bahan kimia yang berasal dari limbah detergen tadi maka bahan kimia tersebut akan masuk melalui insang kedalam aliran darah dan akan mempengaruhi aktivitas ikan.

\section{METODE PENELITIAN}

\section{Waktu dan tempat}

Penelitian ini diadakan pada hari selasa 27 Desember 2016, pukul 11:00-11-30 WIB. Lokasi di Laboratorium Terpadu Techno Park Universitas Islam Lamongan Kabupaten Lamongan

\section{Alat dan bahan}

Penelitian ini menggunakan alat dan bahan sebagai berikut, stopwatch, 6 buah toples, 1 buah timbangan, 1 buah sendok pengaduk, 1 detergen rinso, 6 ekor ikan mas, 2 botol air cleo.

\section{Tahapan Penelitian}

1. Memberi larutan detergen dengan kosentrasi yang berbeda yakni 0 (control), $1 \mathrm{mg}, 2 \mathrm{mg}, 10 \mathrm{mg}$, 20 dan $30 \mathrm{mg}$.

2. Memberi label pada masing - masing toples
3. Menuangkan larutan detergen ke masing-masing toples sesuai dengan labelnya

4. Memasukkan ikan secara kebersamaan

5. Kedalam toples, lalu memulai perhitungan waktu

6. Mengamati ikan pada 5 menit dan 10 menit. Kemudian mencatat hasil pengamatan yang meliputi ikan aktif, lemas, mengambang, mengeluarkan lendir, atau keluar ingsangnya. Atau langsung mati.

\section{HASIL DAN PEMBAHASAN}

Tabel 1 Hasil pengamatan detergen terhadap tingkah laku ikan.

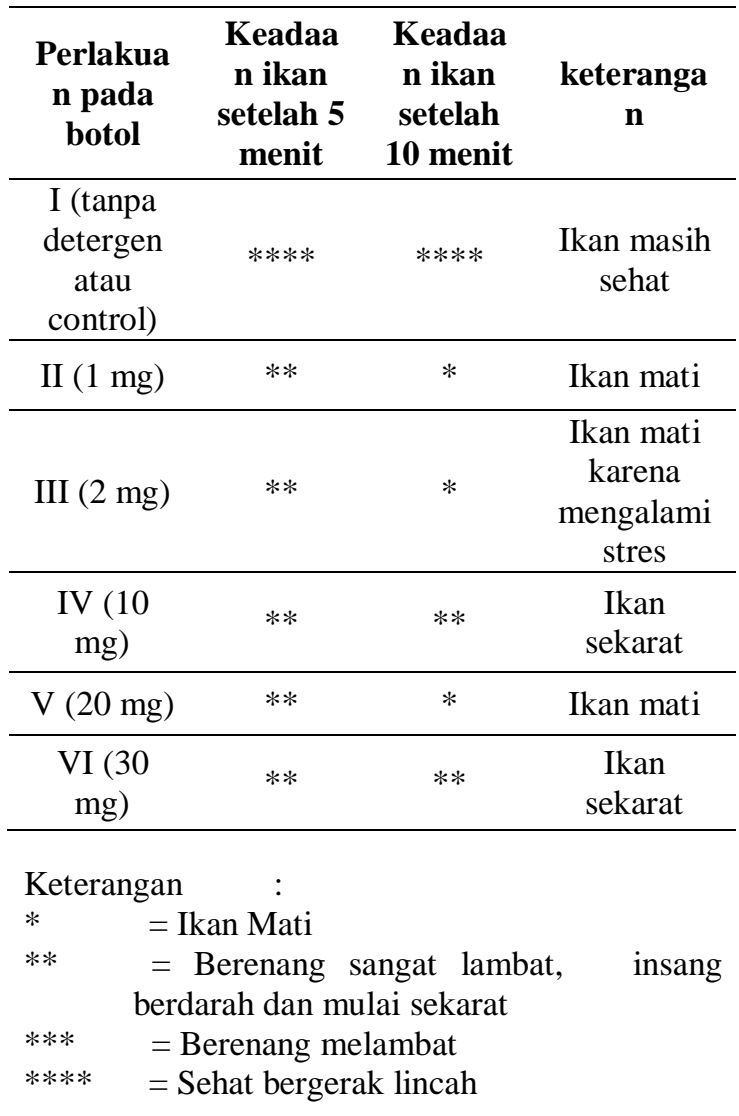

Berdasarkan hasil penelitian pada tabel 1, dihasilkan bahwa ikan hias yang berada di air murni terus bergerak aktif dan tidak mengalami gangguan apapun terhadap insangnya karena lingkungannya normal, tidak tercemar, sedangkan lima ikan yang lainya berenang di air yang tercemari detergen Rinso, mulai dari 1 gram sampai 30 gram, sehinga mereka mengalami ganguan pada organya, terutama insang. Insanya sampai membengkak, berdarah, dan mengeluarkan lendir. Ikan-ikan itupun akhirnya mengambang dan mati. Penyebab ikan itu membengkak, berdarah, lalu mengeluarkan lendir 
adalah difusi. Difusi adalah perpindahan zat dari konsentrasi tinggi ke kosentrasi rendah. Konsentrasi larutan detergen lebih tinggi dari sitoplasma sehingga partikel detergen berdifusi dari larutan ke sel-sel pada insang ikan. Larutan detergen terus menerus berdifusi ke sel-sel insang dan insang pun akhirnya membengkak. Lama kelamaan sel-sel ikan mengalami plasmolisis (pecahnya sel) karena partikel detergen terus berdifusi. Karena selnya pecah, sitoplasma pun ikut keluar, sehingga insang ikan kelihatan mengeluarkan lendir. Setelah sel-sel insang nya pecah,tentu saja ikan kehilangan organ untuk bernafas sehingga ikan-ikan pada larutan detergen lemas dan kemudian mati satu persatu.

\section{KESIMPULAN DAN SARAN}

Berdasarkan hasil penelitian hilangnya fungsi sungai yang sebenarnya yang mengakibatkan pengaruh detergen terhadap tingkah laku ikan menyimpulkan Sebagian besar masyarakat menjadikan sungai sebagai tempat buangan limbah tidak sebagai sumber air, objek wisata, irigasi pertanian, sehingga fungsi sungai yang sebenarnya tidak dapat digunakan dengan seharusnya.

Bagi masyarakat harus mengetahui fungsi sungai yang sebenarnya dan mengetahui efek samping dari pembuangan hasil sisa pencucian karena kandungan yang ada dalam detergen.

\section{DAFTAR PUSTAKA}

Effendi, H. 2003. Telaah Kualitas Air Bagi Pengelolaan Sumber Daya dan Lingkungan Perairan. Kanisius. Yogyakarta.

Herlambang, Y. 2010. Pengelolahan Sumber Daya Alam. Diakses melalui http://www.mediaindonesia.com/webtorial/k lh. pada tanggal 22 februari2011. Https://ide.wikipedia.org/wiki/sungai

Kementrian Lingkungan Hidup. 2004. Pengendalian Pencemaran Air. Jakarta.

Wardhana, W.A. 1995. Dampak Pencemaran Lingkungan Penerbit Andi Offiset. Yogyakarta.

Widjajati, L. 2010. Peran Serta Masyarakat Dalam Pemberdayaan Lingkungan Hidup. 